DOI: https://doi.org/10.36910/6775-2524-0560-2020-41-04

УДК: 004.056.5

Головань Микола Миколайович, студент

Здолбіцька Ніна Василівна, к.т.н., доцент

https://orcid.org/0000-0002-1345-3581

Ліщина Валерій Олександрович, к.т.н., доцент

https://orcid.org/0000-0002-2371-3850

Гринюк Сергій Васильович, асистент

https://orcid.org/0000-0002-0080-3167

Луцький національний технічний університет

\title{
АНАЛІЗ ПРОДУКТИВНОСТІ СИСТЕМИ АВТОМАТИЧНОГО ПОЗИЦІОНУВАННЯ СОНЯЧНИХ ПАНЕЛЕЙ
}

Головань М.М., Здолбіцька Н.В., Ліщина В.О., Гринюк С.В. Аналіз продуктивності системи автоматичного позиціонування сонячних панелей. Встановлено закономірності надходження сонячної енергії на сонячні панелі, закріплені стаціонарно та постійно орієнтовані системою позиціонування перпендикулярно до сонячного випромінювання. Розглянуто специфіку роботи систем автоматичного позиціонування. Встановлено показники відносних втрат енергії у стаціонарних сонячних панелях у порівнянні із їх орієнтацією через систему позиціонування. Доведено, що використання трекерів для сонячних панелей збільшує максимальний приріст річного обсягу вироблення електроенергії на 15 - $43 \%$.

Ключові слова: сонячна енергія, панелі, стаціонарний монтаж, позиціонування, трекер.

Головань М.М., Здолбицкая Н.В., Ліщина В.О., Гринюк С.В. Анализ производительности системы автоматического позиционирования солнечных панелей. Установлены закономерности поступления солнечной энергии на солнечные панели, закрепленные стационарно и постоянно ориентированы системой позиционирования перпендикулярно к солнечному излучению. Рассмотрена специфика работы систем автоматического позиционирования. Установлено показатели относительных потерь энергии в стационарных солнечных панелях по сравнению с их ориентацией через систему позиционирования. Доказано, что использование трекеров для солнечных панелей увеличивает максимальный прирост годового объема выработки электроэнергии на 15 - 43\%.

Ключевые слова: солнечная энергия, панели, стационарный монтаж, позиционирование, трекер.

Holovan M.M., Zdolbitska N.V., Lishchyna V.O., Hrinyuk S.V. The analysis of the productivity of the solar panels automatic positioning system. The regularities of solar energy supply to solar panels, fixed stationary and constantly oriented by the positioning system perpendicular to the solar radiation. The specifics of the operation of automatic positioning systems are considered. The indicators of relative energy losses are astablished in stationary solar panels in comparison with their orientation through the positioning system. It has been proven that the use of trackers for solar panels increases the maximum rise in annual electricity generation by $15-43 \%$.

Keywords: solar energy, panels, stationary installation, positioning, tracker.

Постановка наукової проблеми. Інститут інженерів з електротехніки та електроніки (IEEE) у своїх прогнозах передбачає, що в найближчому майбутньому сучасній традиційній енергетиці на базі викопного палива конкуренцію зможе скласти сонячна енергетика. Потенційні можливості енергетики, заснованої на використанні безпосередньо сонячного випромінювання, $є$ надзвичайно великими. Використавши всього лише 0,0125\% енергії Сонця, можна забезпечити всі нинішні потреби світової енергетики, а використавши 0,5 \% - забезпечити повне покриття потреб на перспективу. Проте на сьогодні в організації основна увага приділяється двом основним проблемам, які гальмують сонячну енергетику як повноцінну заміну викопного палива. Одна із цих проблем $\epsilon$ дороговартісні панелі, друга - незначний ККД. Реально діючі структури з гетеропереходами ККД на сьогодні дають більше $30 \%$, а структури з однорідними напівпровідниками типу монокристалічного кремнію - до 18 \%. Сонячні батареї на монокристалічному кремнії сьогодні видають ККД близько $15 \%$. Проте ці цифри дійсні тільки за умови експлуатації сонячних панелей улітку, ополудні та коли випромінювання $€$ перпендикулярним до світлопоглинаючої площини. Насправді ж Сонце, рухаючись від сходу до заходу, змінює кут падіння та інтенсивність випромінювання [1]. Щоб зменшити вплив цих факторів, забезпечують установлення сонячних панелей стаціонарно в положенні, за якого виробництво енергії буде максимальним, або організовується автоматизоване позиціонування площин сонячної панелі перпендикулярно до падаючого сонячного випромінювання. Відкритим лишається запитання, який із цих методів є енергоефективнішим.

Серед населення стрімко набирає популярності використання сонячних панелей. Зі зростанням кількості сонячних панелей постає питання їхної якості та продуктивності. Один зі способів збільшення виробітку сонячних панелей - будівництво спеціальних конструкцій, що стежать за положенням сонця для забезпечення максимальної ефективності сонячних модулів сонячних трекерів. 
Аналіз досліджень. Автори роботи [8] справедливо стверджують, що дуже швидке використання викопного палива та глобальне потепління викликало зменшення запасів палива. Тому існує необхідність застосування екологічно чистих енергетичних ресурсів для повного задоволення потреб населення в електричній енергії [8]. Автори вважають, що саме сонячна енергія $є$ найбільш ефективним та чистим джерелом енергії, а також дешевим, багатим і вічним джерелом відновлюваної енергії, за допомогою якого можливо подолати залежність сучасного суспільства від звичайних видів палива та ресурсів [8]. Загалом, автори роботи розробили рекомендації щодо широкого застосування сонячних станцій із різноманітною метою: кондиціонування, охолодження, нагрівання за допомогою сонячної енергії [8].

Аналіз останніх досліджень і публікацій $[3,4,5,6,8]$ засвідчив, що основна особливість енергопостачання із використанням сонячної енергії - це непостійність у часі, яка спричиняється обертанням Землі навколо Сонця. Щоб забезпечити необхідну генеровану потужність, необхідно збільшити площу панелей або, якщо це можливо, укомплектувати їх поворотними механізмами. Поворотний механізм забезпечує позиціонування площини панелі перпендикулярно до сонячних променів, залежно від положення Сонця. Окремі автори $[3,4,5,8]$ розглядають шлях розрахунку оптимального кута нахилу сонячної панелі щодо горизонту та кута повороту, за яких можна отримати найбільше енергії із сонячного випромінювання. Проте порівняльний аналіз між системою позиціонування та стаціонарним монтажем сонячної панелі досі не проведено.

\section{Виклад основного матеріалу та обгрунтування результатів дослідження.}

Ефективність (продуктивність) сонячних панелей залежить від багатьох значущих факторів, проте основний $з$ них - орієнтація сонячних панелей щодо Сонця. Очевидним є той факт, що при жорсткому закріпленні сонячних батарей, які підлаштовуються лише на один кут падіння сонячних променів, максимальну кількість енергії виробляється опівдні, коли сонячні промені падають перпендикулярно до їхньої поверхні. Зважаючи на особливості щоденної траєкторії руху сонця, ефективним буде кут повороту панелей близько $150^{\circ}$. Панелі, що зафіксовані в напрямку рівно посередині між точками заходу і сходу, втрачають близько 75\% максимально можливої енергії, виробленої в ранковий і вечірній час. Отже, якщо кут падіння променів на панелі буде малим, то й кількість виробленої енергії зменшиться.

Важливим є також урахування географічних координат розташування сонячної станції, оскільки для півночі України оптимальний кут розташування буде відрізнятися від південних та східних регіонів. При цьому існує потреба вироблення однаково високої кількість енергії протягом усього дня, а також протягом максимального терміну протягом року. Досягаються такі параметри через використання системи позиціонування (трекера), яка через інформацію зі спеціальних датчиків визначає оптимальне положення сонячних панелей та здійснює поворот платформи 3 необхідної сторони та під потрібним кутом.

Сонцем додатково здійснюється сезонний рух між північчю та півднем - за рік воно досягає показника близько $46^{\circ}$. Якщо панелі орієнтуються на середню точку середньорічної траєкторії руху Сонця за напрямом північ-південь, то втрачається генерація близько 8,3...9\%. від максимально можливої кількості. Щоб забезпечити автоматичне стеження за положенням Сонця протягом усього світлового дня та орієнтувати закріплені на них сонячні батареї, використовують динамічні системи кріплення панелей (рухливі трекери). Їх використання забезпечить коригування кута нахилу панелі в залежності від пори року. Такі трекерні установки дозволяють збільшити видобуток електроенергії на $15 \ldots 43 \%$ в порівнянні із нерухомо закріпленими сонячними батареями.

$€$ декілька видів трекерів для сонячних панелей, які керуються різними алгоритмами при виборі напрямку та мають різні приводні механізми. Виділяється два основних типи динамічних систем стеження - одноосьові та двохосьові:

- одноосьові: протягом дня трекер може автоматично змінювати кут в горизонтальній площині. Сонячна станція рухається по траєкторії «Схід-Захід» і може збільшувати свою продуктивність на 10-34\% у порівнянні зі статичною системою,

- двохосьові: трекер рухається і в горизонтальній, i у вертикальній площині, тобто повертається за сонцем для максимальної енергоефективності.

Зміна положення рухомої частини трекера можлива за допомогою ручного приводу, або за допомогою 1-2-х актуаторів - виконавчих механізмів, які здійснюють перетворення одного виду енергії (електричної, магнітної, теплової, хімічної) в іншу (найчастіше - в механічну), що виконує задану керуючим сигналом дію. Встановлення кутів нахилу робочої поверхні, навантаження, іiі строге орієнтування на Сонце є основним завданням трекера. Така орієнтація досягається кількома способами: 
1. Пристрій, що управляється актуаторами через декілька фотодатчиків, здійснює аналіз освітленості при різних положеннях трекера та передає сигнал на актуатори до того моменту, коли потік світла на всіх фотоелементах зрівняється. Завдяки руху Сонця система розбалансовується, це зумовлює подачу імпульсу для активації нового переміщення, зорієнтованого на Сонце. Схеми таких пристроїв не $\epsilon$ складними та дороговартісними, проте за похмурої погоди, при опадах чи забрудненні фотоприймачів система перестає працювати.

2. Переорієнтація системи можлива як вручну, так і через подачу сигналів на актуатори 3 допомогою перемикачів. Проте такий спосіб використовують зазвичай для сезонної орієнтації трекерів, коли на певний період часу виставляють відповідний кут нахилу (на рисунку 1 цей кут позначено як зеніт).

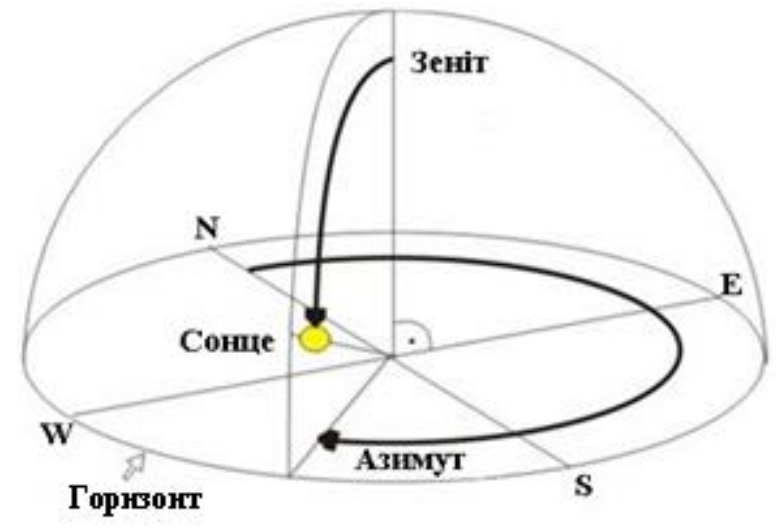

Рис. 1. Зенітний кут нахилу сонця

Рівень точності орієнтації за таких умов буде невеликим, адже постійне перебування оператора біля трекера неможливе, тому даний спосіб є малопоширеним, хоча для сезонної орієнтації невеликих систем він цілком придатний. Для того, щоб управляти рухом трекера за кутами азимута і зеніту, використовують пристрій управління із таймером. Актуатори починають діяти за добовою програмою таймера (якщо необхідно, то і за річною програмою). Але так як протягом року відбувається постійна зміна часу місця сходу і заходу сонця, зенітний кут, то точність орієнтації буде невеликою.

Найбільш ефективним $є$ управління актуаторами за програмою, яка через певний час вираховуватиме місце розташування Сонця. Інформація про значення азимутального (Azimuth) i зенітного (Zenith) кутів із внутрішнього пристрою програмою передається на блок управління. Для переорієнтації трекера виконавчим пристроєм в розраховане положення важливо врахувати місце розташування трекера (широту, довготу, висоту над рівнем моря). Програмою для розрахунку місця розташування Сонця $\epsilon$ алгоритм сонячної позиції (SPA). Пристрої управління трекера розташовуються на захищених комп'ютерах PLC (Програмованих логічних контролерах) або у вигляді окремих пристроїв, які запрограмовані постачальником при поставці трекера із прив'язкою до місцевості свого виробу.

Орієнтація трекера за Сонцем здійснюється трьома способами:

Спосіб 1 - вручну. Цей спосіб є найнадійнішим: сезонна орієнтація трекера виконується оператором вручну, несправності в механічних частинах виникають рідко. Завдяки відсутності вимірювальної апаратури та мінімуму рухомих частин він є максимально надійним, але найменш ефективним.

Спосіб 2 - через фотодатчики. При цьому способі поєднуються два-чотири фотоелектричні датчики, розташовані під кутом $45^{\circ}$ відносно площини панелі $\left(90^{\circ}\right.$ відносно один одного). Датчики розміщуються в оболонках та сприймають тільки вузький промінь світла. За умови, що площина сонячної панелі перпендикулярна сонячному світлу, на кожен датчик будуть потрапляти однакові промені, а напруга на всіх датчиках буде однаковою. Коли Сонце зміститься, то напруга на датчиках почине відрізнятися, і система управління увімкне привід, який відкоригує положення панелі так, щоб напруга датчиків знову була однаковою. Принцип роботи системи нескладний, проте не вважається надійним. У системі управління з фотодатчиками $є$ два суттєві недоліки: по-перше, часте забруднення датчиків, що призводить до збоїв у їх роботі та частого калібрування. Другий недолік нездатність системи працювати в похмуру погоду. 
Спосіб 3 - програмний. Автономну систему управління сонячними панелями програмують відповідно до циклів руху Сонця. Така система є найнадійнішою та не вимагає частого втручання операторів. Основні переваги: швидкість змін програми та можливість віддаленого доступу.

Запропоновано розгляд двох випадків систем монтажу сонячних панелей:

1) стаціонарний;

2) із використанням системи автоматичного позиціонування щодо положення Сонця.

Експерименти проводилися за наступних умов:

1) для першого випадку положення сонячної панелі в просторі: сонячні панелі нерухомі; азимут орієнтації нормалі до поверхні сонячної панелі відносно південного напрямку $\alpha=0^{\circ}$; кут нахилу поверхні сонячної батареї відносно поверхні Землі $\beta=25^{\circ}$, який є оптимальним для Волинської області влітку;

2) для другого випадку позиціонування проводиться неперервно із постійним суміщенням нормалі до поверхні сонячної панелі і напрямку на Сонце: сонячні панелі повертаються по одній осі; сонячні панелі повертаються по одній осі із застосуванням таймера на увімкнення-вимкнення; сонячні панелі повертаються за двома осями; сонячні панелі повертаються за двома осями із застосуванням таймера на увімкнення-вимкнення

Експерименти проводилися у квітні, травні, червені, липні, серпні в одному й тому самому місці на відкритій місцевості протягом 5 днів (по одному дню на кожен вид експерименту) за ідеальних погодних умов (на рисунку 2 представленні значення вихідної потужності кожного місяця), показники вихідної потужності вимірювалися щогодини протягом світлового дня.

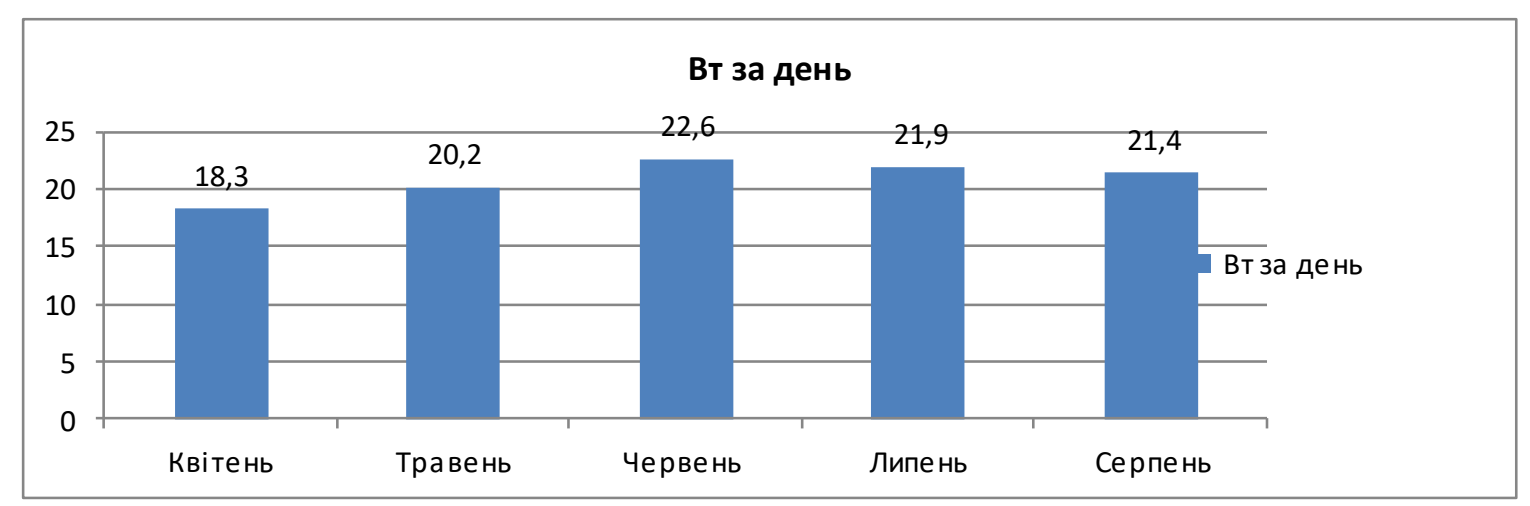

Сонячні панелі нерухомі

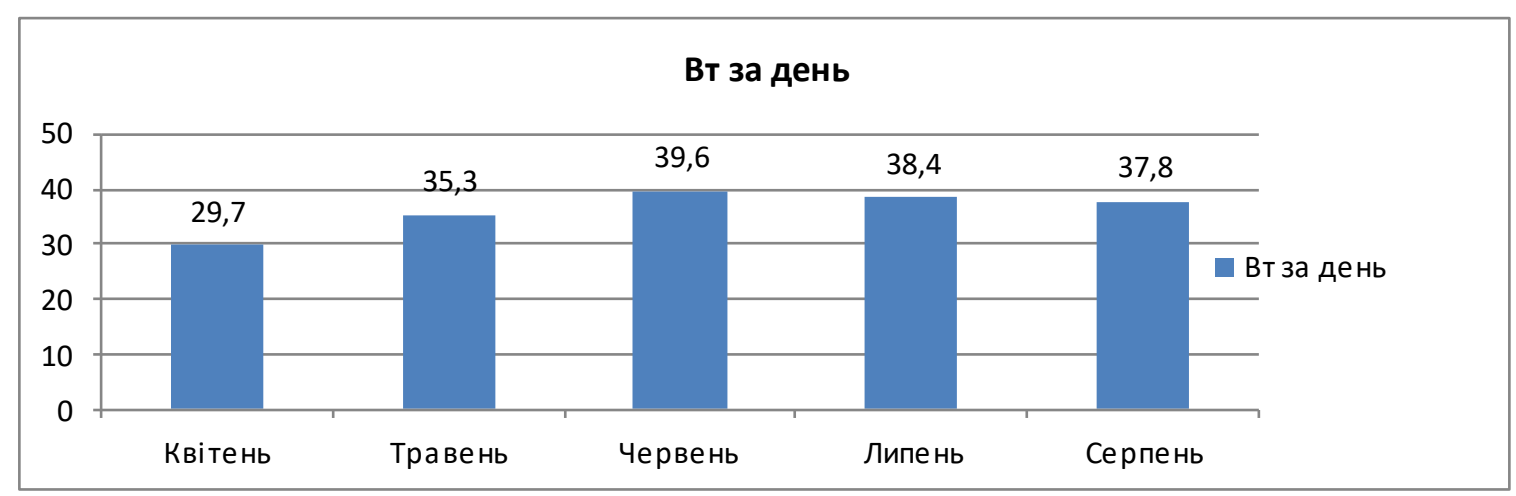

Сонячні панелі поверталися за двома осями

Рис. 2. Значення вихідної потужності 
Щоб розрахувати інтенсивність потоку сонячного випромінювання, що надходить на похилу поверхню сонячних панелей, потрібно визначити кут падіння сонячних променів на них [8]. Розрахунок кутів падіння сонячних променів на поверхню здійснено за формулою (1). При цьому годинний кут $\omega$ розраховано за формулою (2) від 4 до 20 години із кроком 1 година.

$$
\begin{gathered}
\cos \theta=\cos (\varphi-\beta) \cdot \cos \delta \cdot \cos \omega+\sin \delta \cdot \sin (\varphi-\beta), \\
\omega=15 \cdot(12-\tau),
\end{gathered}
$$

де $\beta$ - кут нахилу поверхні сонячної панелі відносно поверхні Землі.

При стаціонарному монтажі сонячна панель $є$ нерухомою, а кількість сонячної енергії, що надходить безпосередньо на поверхню панелі, прямо залежить від коефіцієнту пропускання та коефіцієнту поглинання захисного скла та площі проекції сонячної панелі на поверхню, що $\epsilon$ перпендикулярною рухові сонячних променів.

За формулою (3) розраховано надходження сонячної енергії на стаціонарно змонтовану поверхню для вище зазначених умов.

$$
\mathrm{E}_{\text {п }}=\mathrm{E}_{\mathrm{c}} \cdot \tau_{\text {пр }} \cdot \tau_{\text {пог }} \cdot \sin \left(\theta_{1}\right)
$$

де $\mathrm{E}_{\mathrm{c}}$ - сумарна сонячна енергія, яка надходить на $1 \mathrm{~m}^{2}, \mathrm{BT} / 1 \mathrm{~m}^{2}$.

На основі отриманих даних щодо надходження енергії на сонячні панелі із різною системою монтажу визначено відносні втрати енергії $\varepsilon$ (4) у стаціонарно змонтованих сонячних батареях у порівнянні із орієнтацією їх системою позиціонування.

$$
\varepsilon=\frac{E_{\mathrm{M}}-E_{\mathrm{CM}}}{E_{\mathrm{m}}} \cdot 100 \%
$$

де $\mathrm{E}_{\mathrm{cm}}$ - сонячна енергія, що надходить на сонячну панель упродовж дня при стаціонарному монтажі, Вт·год; $\mathrm{E}_{п}$ - сонячна енергія, що надходить на поверхню, перпендикулярну рухові сонячних променів упродовж дня, тобто при наявності системи позиціонування, Вт·год.

При порівнянні отриманих результатів розрахунків відносних втрат енергії встановлено, що при наявності системи позиціонування та 3 використанням таймера кількість сонячної енергії впродовж дня в 15-43\% більша (рис. 3,4 ).

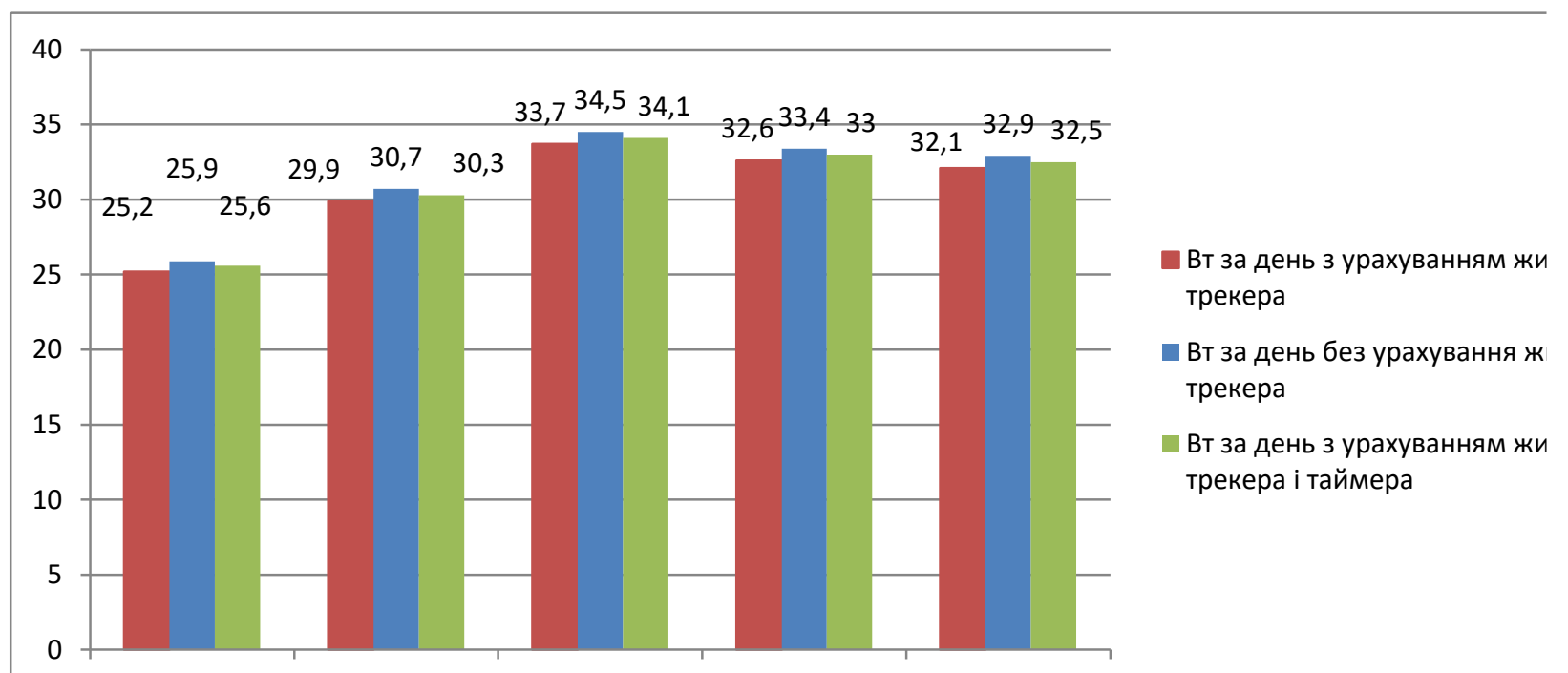

Рис. 3. Порівняння трьох різних видів експерименту при обертанні панелей по одній осі 


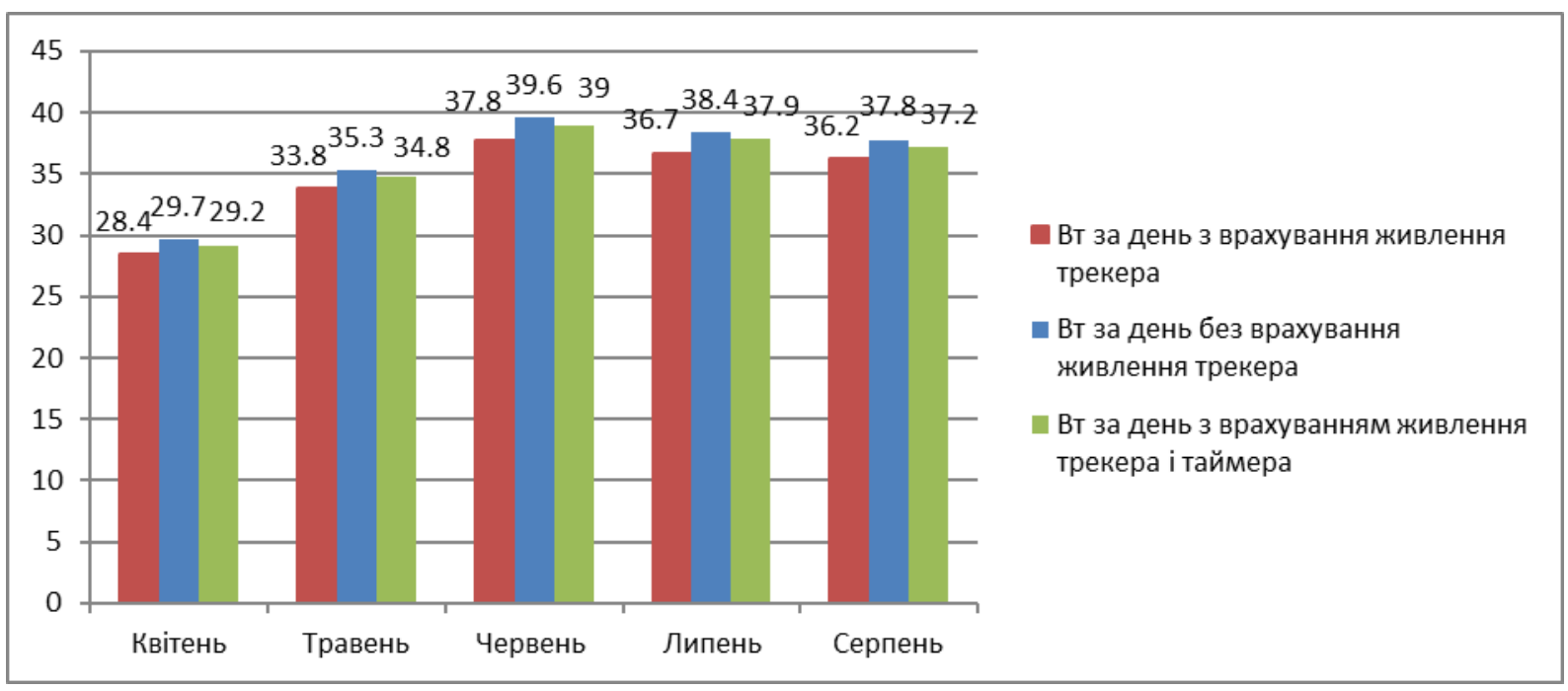

Рис. 4. Порівняння трьох різних видів експерименту при обертанні панелей за двома осями

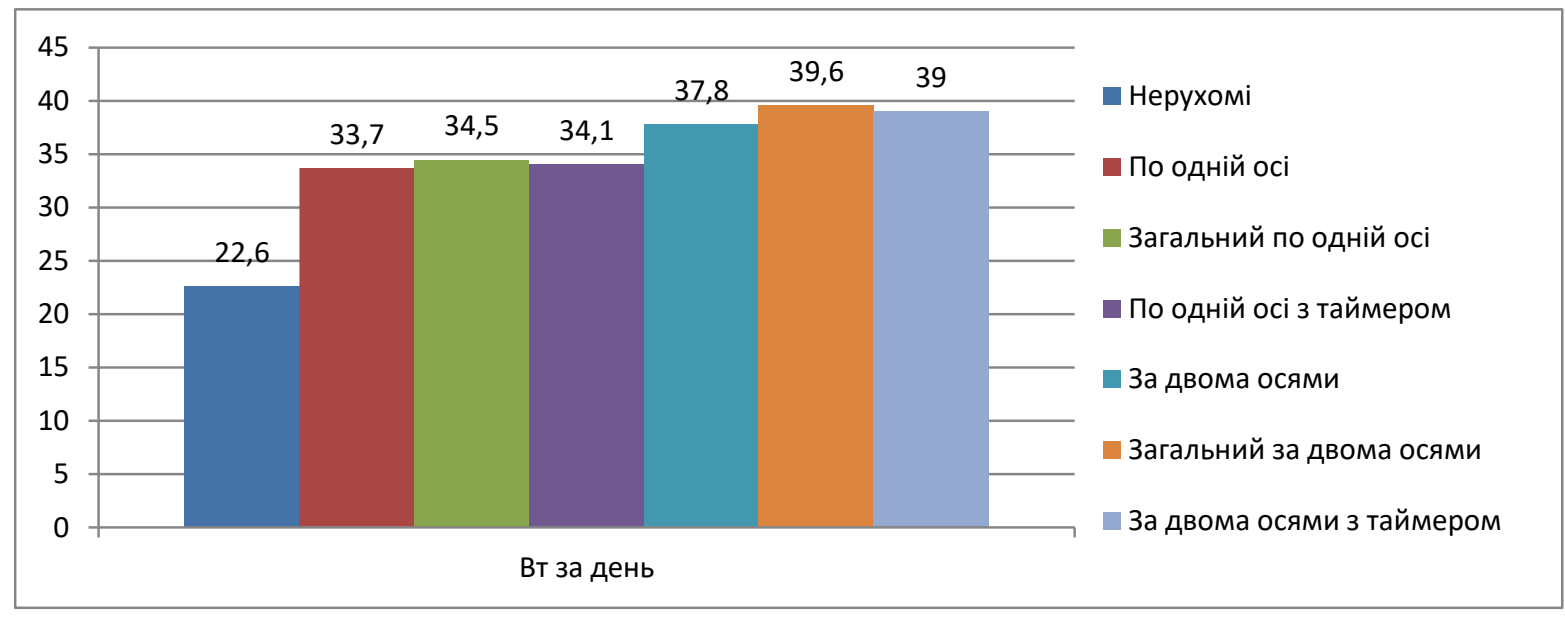

Рис. 5. Результати проведених експериментів за червень

Висновки. Стаціонарний монтаж сонячних панелей передбачає надходження найбільшої кількості енергії тоді, коли випромінювання падає на панель під прямим кутом. В інших положеннях Сонця кількість отриманої сонячної енергії панеллю значно знижується.

Встановлено, що відносні втрати сонячної енергії за стаціонарного монтажу сонячних панелей становлять 15-43 \% (в залежності від пори року). Це є підтвердженням високої енергоефективності систем позиціонування сонячних панелей.

\section{Список бібілографічних посилань.}

1. Гільов В.В., «Переваги та недоліки сонячних батарей та можливості їх використання. Проблеми та перспективи розвитку залізничного транспорту»: 78 Міжнародна науково-практична конференція, 17-18 травня 2018 р. Дніпро, 2018. C. 243.

2. Головань М.М, Здолбіцька Н.В. «Система автоматичного позиціонування сонячних панелей». Збірник тез доповідей ХІІІ Міжнародної науково-практичної конференції «Інформаційні технології і автоматизація - 2020». Одеса, 22 - 23 жовтня 2020. С 284-286.

3. Коваль В., «Енергетична ефективність систем позиціонування плоских сонячних панелей. Енергозбереження». Київ, 2015. випуск 134.

4. Олійник Ю.С. та Машкова О.В. «Ефективність сонячних батарей». Збірник наукових праць: Актуальні наукові дослідження в сучасному світі. Вип. 1 (33), Ч. 1. Переяслав-Хмельницький. 2018. С. 37-39.

5. Серкез Х.В. та Серкез, Яцук В.О. «Оцінювання непевності вимірювання енергетичної освітленості методом електричного заміщення». Збірник матеріалів Всеукраїнської науково-технічної конференції молодих вчених у иарині метрологіï «Technical Using of Measurement-2015», 2- 6 лютого 2015 р. Київ: Академія метрології України, 2015. C. 101-102.

6. Стаднік М.І., Рубаненко О.О., Бондаренко С.В. «Аналіз ефективності генерації електроенергії на основі сонячної енергії в Вінницькій області». Техніка, енергетика, транспорт АПК. Вінниця, 2016. №2 (94) С. 87-97. 
7.Femia N. Power Electronics and Control Techniques for Maximum Energy Harvesting in Photovoltaic Systems / N. Femia, G. Petrone, G. Spagnuolo, M. Vitelli. - CRC Press, 2012. - 366 p.

8. S. Sansaniwal, V. Shanna, J. Mathur. Energy and energy analyses of various typical solar energy applications: A comprehensive review. Renewable and Sustainable Energv Reviews. Volume 82, P. 1. February 2018. P. 1576-160. URL: https://doi.org/10.1016Zj.rser.2017.07.003.

\section{References}

1.Gilov V.V. "The advantages and disadvantages of the solar panels and the possibility of their use. The problems and prospects for the development of the railway transport ": The 78th International scientific-practical conference, 17-18 May 2018. Dnipro, 2018. p. 243.

2.Holovan M.M., Zdolbitska N.V. " System of automatic positioning of solar panels". The collection of the abstracts of the 13-d International scientific-practical conference "The information technologies and automation- 2020". Odessa, October 22-23, 2020. pp. 284-286.

3. Koval V., "The energy efficiency of the positioning systems for the flat solar panels. The energy saving ". Kyiv, 2015. № 134.

4. Oliynyk Y.S., Mashkova O.V. "The efficiency of the solar panels". The collection of scientific works: The current scientific researches in the modern world. № 1 (33), Part 1. Pereyaslav-Khmelnytsky. 2018. pp. 37-39.

5.Serkez H.V., Yatsuk V.O. "The estimation of the uncertainty of the energy illumination measurement by the method of the electrical substitution "The collection of the materials of the Ukrainian scientific and technical conference of the young scientists in the field of the metrology "The technical using of measurement-2015", February 2-6, 2015 Kyiv: The Academy of Metrology of Ukraine, 2015. pp. 101-102.

6.Stadnik M.I., Rubanenko O.O., Bondarenko S.V. " The analysis of the efficiency of the electricity generation based on the solar energy in the region of Vinnytsia". The machinery, energy, transport of the agro-industrial complex. Vinnytsia, 2016. №2 (94), pp. 87-97. 